University of Wollongong

Research Online

Faculty of Business - Papers (Archive)

Faculty of Business and Law

2019

Ontological security as an unconscious motive of social media users

Charles S. Areni

University of Wollongong, careni@uow.edu.au

Follow this and additional works at: https://ro.uow.edu.au/buspapers

Part of the Business Commons

Research Online is the open access institutional repository for the University of Wollongong. For further information contact the UOW Library: research-pubs@uow.edu.au 


\title{
Ontological security as an unconscious motive of social media users
}

\author{
Abstract \\ Reactions to nostalgia-evoking content on social media platforms like Facebook and YouTube suggest an \\ unconscious motive of ontological security, defined as a 'sense of presence in the world as a real, alive, \\ whole, and in a temporal sense, a continuous person'. In addition to the unprecedented access to the past \\ provided by social media, additional factors such as increasing human longevity, the acceleration of \\ technological and social change, the expanded size and greater interconnectedness of social networks, \\ the proliferation of directly and vicariously experienced places and the secularisation of society have \\ contributed to a growing need for ontological security. Engagement with nostalgia-evoking social media \\ content fulfils the need for ontological security by reintegrating memories of the past into an ongoing, \\ self-affirming narrative or 'life story', while the digital archiving of photos and videos offers the possibility \\ of 'digital immortality' for a virtual self that can be projected into the future.

\section{Disciplines} \\ Business \\ Publication Details \\ Areni, C. (2019). Ontological security as an unconscious motive of social media users. Journal of \\ Marketing Management, 35 (1-2), 75-96.
}




\title{
Ontological Security as an Unconscious Motive of Social Media Users
}

\author{
Charles Areni* \\ University of Wollongong
}

*Charles Areni is the Executive Dean and a Professor of Marketing in the Faculty of Business at the University of Wollongong, Northfields Avenue, Wollongong, NSW, 2522, Australia. Tel: +61 24221 5779, Email: careni@uow.edu.au. 


\title{
Ontological Security as an Unconscious Motive of Social Media Users
}

\begin{abstract}
Social media usage has become perhaps the modern pastime, with ever-increasing usage rates and growing concerns about addiction suggesting the need to explore underlying motives for what seems like a growing consumer obsession. Reactions to nostalgia-evoking content on social media platforms like Facebook and YouTube suggest an unconscious motive of ontological security, defined as a "sense of presence in the world as a real, alive, whole, and in a temporal sense, a continuous person”. In addition to the unprecedented access to the past provided by social media, additional factors such as increasing human longevity, the acceleration of technological and social change, the expanded size and greater interconnectedness of social networks, the proliferation of directly and vicariously experienced places, and the secularisation of society have contributed to a growing need for ontological security. Engagement with nostalgia-evoking social media content fulfils the need for ontological security by distorting memories of the past and reintegrating them into the narrative of an ongoing, self-affirming "life story”, while the digital archiving of photos and videos offers the possibility of "digital immortality” for a virtual self that can be projected into the future.
\end{abstract}

Key words: Ontological security, modernity, nostalgia, social media, memory bias, life stories

Summary: The quest for ontological security is a conceptual lens through which consumers' engagement with nostalgia-evoking content on social media can be understood by marketers and other social researchers. 
Social media platforms like Facebook and YouTube host thousands of pages and channels dedicated to nostalgia-related content, each attracting millions of viewers, and hence, a substantial flow of advertising revenue (Trackalytics, 2018). One of these, featuring videos of children's television programs from the 1970s, elicited the following comment by a subscriber:

“In 1971 I was 17 years old and in high school. It was a long time ago and very far away.”

The creator of the channel offered the following in reply:

“I hope this brought you a little closer” (Johnnyboy792, 2012).

The Scottish psychologist R. D. Laing described ontological security as the need for a person to "have a sense of his presence in the world as a real, alive, whole, and in a temporal sense, a continuous person” (Laing, 1965, p. 39). For a person lacking ontological security:

“Time may be comprehended as a series of discrete moments, each of which severs prior experiences from subsequent ones in such a way that no continuous 'narrative' can be sustained” (Giddens, 1991, p. 53).

At a basic level ontological security is "a confidence that most human beings have in the continuity of their self-identity” (Dupuis \& Thorns, 1998, p 27), or more succinctly, “an unconscious need to feel existentially secure” (Phipps \& Ozanne, 2017, p. 362).

When Laing (1965) initially coined the term “ontological security”, he was interested in understanding the psychological condition now referred to as dissociative personality disorder, but he understood its relevance to psychologically healthy people, referring to the fundamental existential need to maintain a sense of a continuous self who exists over time. Rather than an absolute distinction between pathological and psychologically healthy states, 
ontological security varies along a continuum, and a person's position on that continuum can change. A person can experience ontological insecurity from time to time depending on “ordinary circumstances of everyday life” (Laing, 1965, p. 42).

In particular, “an external environment full of changes” often makes people feel ontologically insecure because earlier versions of the self from childhood, adolescence, early adulthood, etc., become psychologically distant from the present version of the self (Giddens, 1991, p. 53). Life-changing events like marriage, starting a family, divorce, the loss of a loved one, and so on can sometimes result in a schism of the self over time, such that a new and vastly different self finds it difficult to connect with the prior selves that existed before. The remembered past is experienced as being psychologically remote and not a part of the present self, as with the YouTube poster quoted above. Nostalgic yearnings for the past often reflect an unconscious desire to reacquaint with former selves and reintegrate them into a narrative account of a life that includes the present self.

Individuals have a fundamental need to perceive themselves as real people who have existed in the past and continue to exist, but the desire to maintain continuity of the self over time also extends forward in time (Belk, 1988; Taylor, 1989). The human awareness of impending mortality poses unique challenges to maintaining a sense of ontological security because the self cannot indefinitely extend into the future (Giddens, 1991). This threat to ontological security can provoke an unconscious desire for immortality, which can manifest itself in the pursuit of fame, status, wealth, and other pathways into history's pages, allowing the self to transcend the limits of mortality (Becker, 1973).

Research suggests a compensatory mechanism between threats to past, present and future selves. When the present is particularly bleak, the self takes refuge in remembering the past or anticipating the future (Frankl, 1959). A threat to the future self, such as an event that makes mortality particularly salient, leads people to maximise happiness in the present 
moment (Frankl, 1959), or reflect on their personal pasts as a source of psychological comfort (Juhl et al., 2010; Routledge et al., 2008; Zhou et al., 2013). Likewise, a threat to a self that existed in the past but can no longer be, like the loss of a cherished person, place or thing, often requires the formation of a future self that has "moved on with her/his life" to promote psychological recovery (Fielden, 2003; Michael \& Snyder, 2005)

Related to the idea that each human being has a fundamental need to view himself as a single self that exists over time, is the notion that this existence, this life, is one worth living. Each person is motivated to believe that her life has purpose, meaning and inherent value (Frankl, 1959). The need for a sense of purpose leads a person to reflect on the past and connect previous versions of the self in a meaningful way over time. The present self seeks to verify and validate earlier selves in pursuit of identity and meaning, essentially ensuring that the past does not become obsolete, while at the same time pursuing a legacy that will persist after the biological self ceases to be (Taylor, 1989).

The theory presented below interprets consumers' actions and interactions on social media platforms like Facebook and YouTube as reflecting an underlying need for ontological security. As shown in Figure 1, several aspects of modern life have led to a growing sense of ontological insecurity and the burgeoning use of social media. Social media have increased the opportunity to experience nostalgia by providing unprecedented access to the past, while the growing sense of ontological insecurity has increased consumers' motivation for nostalgia experiences in order to reconnect with previous versions of themselves. Nostalgia experiences on social media promote ontological security by establishing social networks of people who can share and verify experiences from the past. By re-experiencing "blasts from the past”, social media users are recovering their former selves and re-integrating them into the personal narrative of their life. Various memory biases facilitate the integration of remembered 
experiences into a biographically coherent, self-affirming, yet entirely plausible, life story; the legacy of a life well-lived.

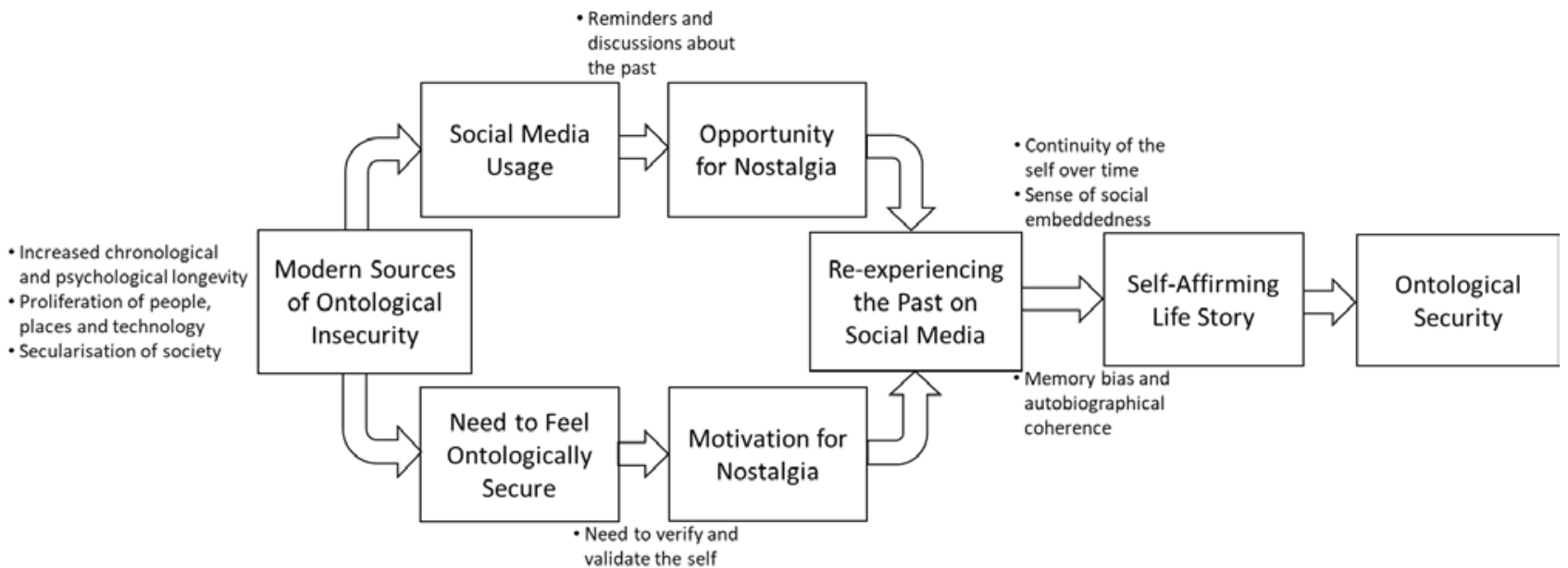

Figure 1: Modernity, Social Media, Nostalgia, Life Stories, and Ontological Security

\section{Modern sources of ontological insecurity}

Several scholars have linked growing concerns about ontological security to specific aspects of what is often referred to as modernity (Bauman, 2000; Gergen, 1990; Giddens, 1991). The term “modernity” itself is temporally imprecise, and indeed, some of the sources of ontological insecurity discussed below pre-date the industrial revolution, others have emerged within the last few decades, and still others are difficult to pinpoint as beginning in any specific decade. Nevertheless, as shown in Figure 1, increases in human longevity, accelerating rates of technological change, the expansion of social networks beyond the constraints of physical proximity, the multiplication of places and spaces inhabited, and the decline of religious influence, have all contributed to unconscious feelings of ontological insecurity. 


\section{Increased chronological and psychological longevity}

At least part of the modern preoccupation with ontological security stems from one demographic fact. Humans live longer than ever before, and this increase in longevity has been rather sudden. Average life expectancy in Ancient Greece was 37 years. Not much changed over the next 2000+ years. In the US, for example, average life expectancy was just 42 years in 1890 (Landis, 1947). Today the figure sits at almost 80 years (Hambleton et al., 2015; Wilmoth, 1998, 2000). The net effect of this dramatic increase in human longevity over a relatively short period is that people have longer personal pasts to keep track of than ever before, and as suggested by the comment of the YouTube user in the opening paragraph, many of these former selves seem very psychologically distant.

Another effect of increasing human longevity is a shift in the demographic composition of many societies. Just a few generations ago, only a very small percentage of the population was 65 years of age or older. This is no longer the case. Now, for example, over $15 \%$ of Australians are 65 or older, and septuagenarians and octogenarians are a significant part of the demographic landscape. The number of Americans aged 85 or older has almost doubled in the last two decades (Wilmoth, 1998, 2000). All these senior citizens in our midst have affected how we think about our own mortality because most people who die are indeed old. This was not always the case. Two centuries ago death was distributed much more evenly over the life span. Disease, violence, accidents, and malnutrition played greater roles in who lived and who died, and these malaises could strike at any age. An aging population creates another fundamental threat to ontological insecurity - constant reminders of impending mortality (Giddens, 1991; Routledge et al., 2013).

However, increases in chronological longevity may actually pale in influence compared to recent increases in psychological longevity. When people reflect on a period of their past, perceived duration is influenced by how many distinct events they can recall as having 
occurred during the interval. The more somebody can recall as having happened in between the beginning of the target interval and the end, the longer the period is remembered as having been (Bailey \& Areni, 2006; Zakay \& Feldman, 2003). How long ago does high school graduation seem? If someone can remember many things as having occurred between that event and now, then the event gets pushed further back in terms of psychological time; it "seems like a lifetime ago"; but if very few events come to mind as having occurred in that interval then it “seems like only yesterday” (Zauberman, Levav, Diehl \& Bhargave, 2010).

\section{The proliferation of people, places, and technology}

Modern life is simply associated with more distinct events in memory per year, per month, per week, and per day than has been the case for much of human existence due to increasing rates of technological and social change, which fracture and fragment existence into multiple distinct events in a variety of ways (Bauman, 2007). Over the last two centuries technological advances have accelerated the rate at which new products disrupt everyday life, increased the size of social networks - the number of relationships people must manage and keep track of, expanded the volume and geographic scope of the information people regularly receive, and multiplied the spaces and places people occupy (Gergen, 1999; Zerubavel, 2003).

E.H. Gombrich captured this aspect of the psychological effects of accelerating technological change perhaps better than anyone else when he wrote that "our own past is moving away from us at such frightening speed.” (Gombrich, 1967, p 65), an idea reflected in the comment of this social media user.

“1999 was a pretty long time ago in terms of media. The cultural turnover rate is so fast now, even five years is like a lifetime in some respects” (JoymanyMahn2, 2008). 
Eviatar Zerubavel and Svetlana Boym suggest a more explicit link between accelerated technological and social change and the growing need for ontological security.

"Yet the continuity between the past and the present is also disrupted nowadays by the tremendous acceleration of social and technological change ... has triggered an unmistakably conservative urge to ... conserve the old ways of life” (Zerubavel, 2003, pp. 38-39).

“The rapid pace of industrialization and modernization increased the intensity of people's longing for the slower rhythms of the past, for continuity, social cohesion, and tradition” (Boym, 2001, p. 16).

\section{Secularisation of society}

Another important aspect of modernity is the steady decline of religious influence (Taylor, 2007). Throughout human history, religions have provided a veritable script for how to live a good life, and one that was widely shared by members of a community (Becker, 1973). No such authority or consensus exists in modern, secular societies, where lifestyles have become increasingly idiosyncratic. Each person must write his own script (Giddens, 1991; Bauman, 2007). Other identity affirming institutions like government (i.e., being a patriotic, law abiding citizen), places of employment (i.e., job titles, promotions, career progression), and the family (i.e., being a loving spouse, good parent, doting grandparent), have also waned in influence (Bauman, 2000, 2007), but the decline of religion has played a definitive role in the modern loss of identity (Taylor, 2007).

When we consider the role that religion plays in maintaining a sense of ontological security, the rites and rituals that characterise most forms of faith are particularly relevant. Religious rites are often about marking fundamental transitions from one stage of life to the 
next (Taylor, 1989; 2007). For example, in Catholicism, communion represents being old enough to participate in adult activities like church ceremonies, confirmation symbolises adulthood, then, of course, there is marriage, baptism of a newborn, funerals for lost loved ones, etc., all symbolising a fundamental shift from one phase of life to the next (Pargament, 1997, 2002; Rosenblatt, Walsh \& Jackson, 1976). Without religious influence, these major transitions in life may be harder to resolve, resulting in a fragmented past, and hence, a threat to ontological security.

Many religions also involve a belief in an eternal afterlife as a kind of palliative for existential pain. Living in accordance with prescribed principles in pursuit of eternal afterlife has historically been source of purpose and meaning for many people throughout the ages (Taylor, 1989). Death is not the end; it is merely a transition between a finite existence and an infinite existence. When these kinds of religious beliefs are no longer widely adopted by members of a society, the need for ontological security is heightened for at least two reasons. The rewards for virtuousness are less clear, and ontological security is threatened by the absence of an afterlife.

The net effect of the decline of religion and other life affirming institutions is that individuals are on their own to discover sources of meaning and purpose. The marketplace offers possible solutions to the problem of ontological security via the acquisition of products that provide a sense of identity and purpose (Belk, 1988), but these customised solutions require many choices, and never quite provide the same sense of certainty. Modern consumers may not be psychologically equipped to identify marketplace solutions to their ontological insecurity dilemma (Becker, 1973; Bauman, 2007).

To summarise, increases in longevity, accelerating rates of technological change, larger social networks, and more numerous places and spaces inhabited have made it harder for consumers to weave memories of the past into a "sense of presence in the world as a real, 
alive, whole, and in a temporal sense, a continuous person” (Routledge, Arndt, Sedikides \& Wildschut, 2008). At the same time, institutions that have historically provided a sense of identity and purpose in life, especially religion, have waned in influence, leaving consumers exposed to a growing sense of ontological insecurity. Social media platforms like Facebook and YouTube may provide consumers with a means of capturing or recapturing their personal pasts and reconfiguring them into coherent, continuous, life-affirming narratives, hence reestablishing a sense of ontological security.

\section{Social media usage as a modern consumer pastime}

Social media usage is emerging as the ultimate consumer pastime, with both positive and negative outcomes for users. So ubiquitous is the influence of social media, that consumers have developed a new vocabulary (i.e., "tweeting followers”, “posting a new selfie", "tagging a friend”) to describe the various ways they engage with platforms like Facebook and YouTube. Indeed, it is difficult to overstate the suddenness with which social media has fundamentally transformed how people behave on a moment-by-moment basis, so understanding the underlying motives for spending hours a day using these products is a worthy topic for consumer researchers.

The continuing rise of social media

Adult usage of social media has increased from 21\% of the population in 2008 to $79 \%$ in 2016 (Poushter, 2017). Facebook and YouTube remain the most popular platforms, with 68\% and 73\% of all adults as users as of 2017 (Smith \& Anderson, 2018). Although usage initially skewed toward younger adults, social media has caught on with older consumers. Among senior citizens, usage of at least one social media platform grew from $2 \%$ in 2008 to 
$34 \%$ in 2016, and the usage among adults aged 50-64 increased from $7 \%$ to $64 \%$ in the same period (Brenner, 2013; Poushter, 2017; Zickuhr \& Madden, 2012).

In 2014, users were spending roughly 22 minutes per day on social media (Wells \& Link, 2014). By 2018, research based on actual mobile phone usage data estimated that this had increased to 2 hours and 12 minutes per day (Giunchiglia et al., 2018). Although usage rates tend to vary depending on how usage is measured (Anderson et al., 2012), some studies have placed usage rates at as high as over six hours per day (Pornsakulvanich, 2017). The development and rapid diffusion of fourth generation, or 4G, mobile phones only exacerbated social media usage by providing on the spot, around the clock access to platforms like Facebook, Twitter and YouTube. Instead of having to sit down at a desktop or laptop computer to post new material and view the posts of friends and family, consumers now had access to a camera, video-recorder, and multiple social media apps right in their hip pocket.

\section{The darker side of social media usage}

Some researchers have suggested that excessively high levels of social media use on smart phones is a kind of modern addiction (Gokcearslan et al., 2016). Claims of addiction are fuelled by the testimonies of users who have described physical withdrawal symptoms after trying to go “cold turkey” on social media (Amigo, Osorio \& Bravo, 2017). Concerns about addiction have led to the emergence of "time out" centres designed to ween children and adolescents from constantly texting and posting updates to their friends (Acharjee, 2016), and the creation of a social media disorder questionnaire designed to measure the extent of addiction (van den Eijnden, Lemmens \& Valkenburg, 2016).

Some social media users admit to trying to make friends envious as a primary motive for posting photos (Acharjee, 2016; Storr, 2017). This is particularly true of the "selfie"/social media nexus, where users take photos of themselves engaged in various activities and post 
them on social media platforms like Facebook and Instagram. Studies have estimated that over 93 million selfies are taken every day, with over 1000 posted on social media every ten seconds or so (Senft \& Baym, 2015).

The preoccupation with posting selfies on social media is so strong that some photos have been the cause of suicides and attempted suicides, due to people being unhappy with the quality of their self-photos or receiving negative comments by others, and accidental deaths due to people unwittingly putting themselves in harm's way trying to get the perfect shot (March \& McBean, 2018; Senft \& Baym, 2015; Storr, 2017). Recent articles in the medical literature have coined the expression "Snapchat dysmorphia” to describe how posting selfies through social media filters can lead to body dysmorphic disorder - an expectation that the poster's actual body should look like the digitally enhanced person in the photos posted on social media (Rajanala, Maymone \& Vashi, 2018).

\section{Positive psychological consequences of social media usage}

However, not everything is negative when it comes to the bourgeoning influence of social media on consumer behaviour. At their most basic level, social media allow users to capture, organise and manage their personal experiences as digital archives that catalogue important life events. The fact that these memories can be re-experienced and shared with significant others as viewed photos and videos may play a decisive role in helping modern consumers maintain a sense of ontological security. What social media may inadvertently provide to modern consumers is a way to tell the story of their lives and create a lasting digital legacy of all they have done and experienced.

These uses of social media may create a sense of ontological security by extending the continuity of the self in both temporal directions. The past can be preserved, organised and reorganised according to the needs of the present self, and embellished via the biased 
memories and comments of others well-known to the poster, or verified via the likes and posts of complete strangers who were, nevertheless, around at the same time and who experienced similar things. The same social media tools also allow the self to extend forward in time as a digital archive of a life well lived, giving future generations a potential glimpse into who the poster was and how she lived. These potential positive effects of social media usage are explored in detail below.

\section{Opportunities and motivations for nostalgia on social media}

The theory presented in Figure 1 links the modern quest for ontological security to the unparalleled access to the lived or personal past provided by social media. Whereas in previous generations consumers constructed their personal pasts from autobiographical memories, discussions with others who experienced the same events, photo albums, home video collections, and mass media content, they now have access to almost unlimited personal and public material with which they can continually access and reconstruct their personal history (Belk, 2013).

Social media platforms have facilitated the pursuit of nostalgia by allowing users to post original content (i.e., creation) or content produced by others (i.e., curation) (Duggan, 2013). Facebook and YouTube are preeminent in terms of nostalgia content. For example, the Facebook page of Do You Remember? has over 5.8 million followers, whereas its Twitter and Instagram sites have only 65,800 and 109,000 followers, respectively (Do You Remember, 2018). Likewise, Canal Nostalgia has over 11 million subscribers on YouTube, but less than half that many followers on Twitter and Instagram (Canal Nostalgia, 2018). In addition to having the highest usage rates among social media platforms, Facebook and YouTube have the most balanced demographic profile with respect to age (Smith \& Anderson, 2018), 
suggesting that they are used by multiple generations to access the past various periods of the past.

However, not all memories of the past elicit sentiments of nostalgia, and not all aspects of nostalgia are equally relevant to establishing and maintaining a sense of ontological security. It is important to be conceptually precise about what kinds of nostalgia experiences on social media are relevant and how they make users feel more ontologically secure. Given the purpose of understanding social media usage as an unconscious pursuit of ontological security, the focus here is on nostalgia for remembered experiences from an earlier period of one’s own life. The primary motives involved are rediscovering former versions of the self, and reintegrating these lost selves into a personal narrative that leads up to the present self (Boym, 2001). As depicted in Figure 1, verification and validation of the self is a fundamental motivation for these kinds of nostalgic experiences (Kessous, 2015). Nostalgia is "one of the ways that one develops and maintains identity" and is "the primary means by which one maintains relationships with old parts of the self and by which one measures personal change over time” (Cavanaugh, 1989, p. 63).

\section{Reminders and discussions about the past}

Social media provide almost unparalleled access to users’ previous experiences as well as several tools for managing and embellishing the past. In addition to user-generated content like family photos, vacation "selfies”, wedding videos, etc., various social media platforms include deliberate prompts to hurdle users into the past. Facebook does this by automatically “sharing” a memory. A series of photographs from five, six, even ten years ago appear, challenging users to remember whom they were with, where they were, what they were doing at the time, and why. A variation on this theme occurs when two users receive automatic notifications of their anniversary of becoming friends on Facebook. Notifications feature a 
series of photographs showing the two friends over the years, again facilitating a trip down memory lane. More recently, Facebook initiated “first photo” and “year in review” prompts, again reminding users of images posted many years earlier (Zhao et al., 2013).

Facebook can create ad hoc social networks of people who did not know one another prior to posting a comment about some nostalgia-evoking meme. Simply by posting a comment, users can see the comments of hundreds and even thousands of other users outside of their immediate social network, and can respond to those users directly. YouTube is perhaps an even more powerful source of nostalgic material. Users can find movie clips, television programs, advertisements, and other video content from any era since the advent of photography, and share their personal reactions to, and previous experiences with each photo or video, allowing them to connect each clip to childhood activities, family rituals, social networks, school experiences, and personal memories from the past (Lange, 2011; Pett, 2013; Piper, 2011). This material can provoke extended exchanges of comments among previously unconnected users who unite to form an ad hoc social network to discuss common memories (e.g., “Yes, I remember watching this too!”), an essential aspect of maintaining a sense of ontological security (Giddens, 1991).

Need to verify and validate the past

Research examining reasons given for using social media suggest an underlying motive of ontological security. Users discuss a desire to reconnect and stay in touch with friends from the past (i.e., the old neighbourhood, high school and college classmates, former teammates, etc.). Older users often cite the more specific goal of communicating with children and grandchildren, suggesting desire to stay affiliated with younger generations, and an awareness of passing time (Nef, Ganea, Müri \& Mosimann, 2014). Users also cite sharing information about major life events has a motive. Facebook is the most frequently used social media platform for this purpose (Luchman, Bergstrom \& Krulikowski, 2014). 
Facebook users implicitly refer to nostalgia and ontological security when describing their motives, noting that revisiting the past verifies, and hence provides a sense of comfort, that previous experiences really happened (Zhao et al., 2013). This is perhaps why consumers are more prone to purchasing nostalgic products when they experience an existential threat (Zhou et al., 2013). Reacquainting with a former self in this way may psychologically offset the threat to a future self, suggesting a kind of compensatory relationship for distributing the self over time.

The sheer power of the emotions expressed suggest that something more than simply reminiscing is occurring in these social media exchanges.

"I am spellbound looking at him in this video. A special part of my childhood just awakened and came to life. The tears are flowing out of my eyes” (Pannoni, 2013). Research has shown that a significant proportion of nostalgia-related posts on social media reflect religious themes, with terms like “God”, “Jesus”, “prayer”, and “prophet” appearing frequently. Further, cluster analyses of Facebook posts have identified two thematic dimensions suggestive of ontological security as an underlying motive - one labelled “Christianity” and the other "Spiritual path” (Davalos et al. 2015). In this sense, nostalgia may be a kind of modern substitute for religion for validating one’s life, a fundamental requirement for achieving a state of ontological security (Giddens, 1991). Indeed, some researchers have posited a connection between the fall of religiosity and the rise of nostalgia in modern life (Freeman, 1998).

Although nostalgia experiences on social media elicit comments suggestive of ontological security as an underlying motive, the process by which these experiences make consumers more ontologically secure has not yet been fully specified. The following section describes how nostalgia-laden memories are distorted such that consumers’ personal pasts 
take on a biographically coherent, narrative structure, allowing for the formation of a continuous, self-affirming life story.

\section{Maintaining self-affirming life stories}

Ontological security entails the need to validate one’s existence, particularly at advanced stages of life (Routledge et al., 2013). One way to fulfil this need involves distorting memories of the past. Consumers tend to remember various episodes in their lives as being better than their actual experiences were at the time. Autobiographical memories are distorted to create a more positive narrative account of the past, subject to the constraint of maintaining a plausible and continuous conception of themselves as existing over time.

As shown in Figure 1, constructing a plausible yet laudable life story is central to the pursuit of ontological security, and nostalgia plays a critical role in this process. David Lowenthal, quoting Frederick Wyatt within, captures this essential psychological function of nostalgia:

“The past is integral to our sense of identity; 'the sureness of "I was" is a necessary component of the sureness of “I am”" (Wyatt, 1964, p. 319). Ability to recall and identify with our own past gives existence meaning, purpose, and value ... to know what we were, confirms that we are. Self-continuity depends wholly on memory” (Lowenthal, 1985, pp. 41, 197).

Maintaining a sense of continuity of the self over time is a fundamental motivation for nostalgic experiences (Kessous, 2015). Nostalgia is “one of the ways that one develops and maintains identity" and is "the primary means by which one maintains relationships with old 
parts of the self and by which one measures personal change over time” (Cavanaugh, 1989, p. $63)$.

\section{Continuity of the self over time}

In order for the self-concept to emerge as a viable protagonist in the life story, there must be some way of connecting all the former selves represented in the life story with the current self (Belk, 1988, 1991). The need to go back in time to an earlier phase of one’s own life is not so much an escape from modernity or technological innovation as much as an attempt to connect a previous version of the self in memory to the present version, which exists in a radically changed world (Pickering \& Keightley, 2006). Yet, the fragmentation of modern existence has made the maintenance of identity over time increasingly difficult because there are too many past selves to assemble into a coherent whole (Bauman, 2000).

Nostalgia is a way of reacting against these aspects of modern life, and attempting to slow down the pace and fragmentation of daily existence (X. Huang, Huang \& Wyer, Jr., 2016). Consumers now have more remembered people, places, lifestyles, and ways of doing things to keep track of than ever before (Bauman, 2007). Many of the former selves who knew these people, lived in or visited these places, used these obsolete tools and devices, and lived these experiences seem ever further back in psychological time, which has created a corresponding need to recover these lost portions of our pasts (Pickering \& Keightley, 2006). Nostalgia provides a way of representing these former selves as a single protagonist who was different in the past, has evolved over the years, but is, nevertheless, the same person existing over time (Ju, Kim, Chang \& Bluck, 2016; Lasaleta, Sedikides \& Vohs, 2014).

In addition to providing unprecedented access to past, social media also facilitate the construction of a personal narrative - the story of a protagonist that has existed over time. For example, the timeline function of Facebook, introduced in 2012, made it easy for users to 
organise content from the past into a visual, linear account of their lives (Belk, 2013; Zhao et al., 2013). Research suggests that Facebook users have developed a language and classification system for determining which photos and videos will become part of their life story and which will simply be deleted by "untagging” it. When a photo becomes old enough, the user must decide whether it remains in their Photos and Timeline areas, or whether it is untagged and essentially erased from their life story.

Perhaps not surprisingly, content related to major life events tends to remain in users’ timelines. Indeed, Facebook has been described as “An Identity Platform that Extends in Time” (Zhao et al., 2013, p. 5). So effective are these timeline and archive functions of Facebook at helping users create and maintain a life story that many spend so much time on these tasks that their online "self" comes to feel more real than their actual self (Acharjee, 2016; Amigo et al., 2017).

However, users of social media are not just capturing and organising their pasts, these platforms for archiving digital representations also allow users to extend their selves into the future, achieving a kind of digital immortality (Belk, 2013). Users establish continuity of the self in both temporal directions. The past is recovered, preserved, and organised into a narrative structure that can be projected well into the future as a digital record of a life welllived (Bell \& Gemmell, 2009). The human body, and the "bio-memories” it creates, cease to be, but "e-memories" in the form of posted photos, videos, and other digital mementos are potentially eternal.

Recognising this possibility, some researchers have even identified the need for digital funerals and estate planning, with instructions for how the remaining digital legacies are to be managed, long after the protagonist of the life story depicted has ceased to be (Bassett, 2015), suggesting an awareness of a digital self that will long outlive the biological self that created it. The notion that the self can continue after death is not new (Belk, 1988), but the advent of 
digital photos and videos, combined with the Internet, and more recently social media, greatly enhances the possibilities for post-mortem representations of the self (Belk, 2013).

Indeed, some researchers have proposed that the self can be represented by multiple relics, some digital and some physical, having different distributions over space and time (Graham, Gibbs \& Aceti, 2013). A physical remnant like a science award received in fifth grade may have different distributions over time, depending on how it is stored and whether it is a paper certificate or a wooden plaque with stainless steel plating. Likewise, a digital photo of the person receiving that award can have different distributions in time and space, depending on its storage, the number of uploads to social media, and privacy settings on a Facebook account.

Researchers have also described multiple ways in which the digital self can be represented in perpetuity. "One-way” immortality involves digital archives that can be viewed by others after death, but do not otherwise respond to the outside world. However, the future may give rise to a kind of "two-way" immortality wherein the digital self can evolve over time, engage with multiple communication platforms like email, social media, and text chat, and exchange information between these platforms (Meese, Nansen, Kohn, Arnold \& Gibbs, 2015; Savin-Baden, Burden \& Taylor, 2017).

\section{Social embeddedness of the self}

Ontological security often requires the verification and validation of the past. The self cannot allow previous chapters of its life story to become irrelevant. One approach to rediscovering and affirming an earlier version of the self is via the confirmation from others who also existed during that period and can remember the same things. Social media platforms like Facebook and YouTube allow for this kind of verification because they can create, ad hoc social networks of people who did not know one another during the bygone era 
but who can, nevertheless, share their memories of that time period years later (Davalos et al., 2015; Koetz \& Tankersley, 2016). Relying on friends, followers, and other unknown users of social media to affirm that they remember the same things, that they were there too, that something really happened is essential to maintaining ontological security because this verifies past selves and re-establishes connections to the present self (Wildschut, Bruder, Robertson, Tilburg \& Sedikides, 2014). Social media users can interact within existing social networks or establish new ones to confirm that they did indeed live in some period of the past. Hence, it must be real; their past selves must have existed, as expressed in the following YouTube comment.

"We can all connect with this, all of us were little kids watching this. ... Who would have ever thought we would talk to each other on a computer or watch a precious memory like this. I was there watching this just like you” (Musicom Productions, 2007).

What is critical about the spread of these ad hoc social networks is that, not only are the participants rediscovering a long lost versions of themselves, they are also interacting with a congregation of others who can verify that period of the past (see Lasaleta, Sedikides \& Vohs, 2014). Social media platforms like Facebook and YouTube foster this kind of narrative construction by inviting multiple users to comment and form ad hoc social networks relevant to elements of each user's personal past. Visual and aural stimuli trigger the memory of seemingly long lost experiences from the past, allowing posters to recapture and reintegrate previous versions of themselves into their life story (Belk, 2013).

This sense of social embeddedness validates the memory of a former self, connecting it with others who can testify that this period of the past was real and experienced by many who are still alive (Loveland, Smeesters \& Mandel, 2010). Hence, the remembered experiences 
seem entirely plausible, but at the same time, since each poster is motivated to represent their past in a self-affirming light, the memories are infused with positive sentiment. Each poster remembers the past through the same wistful, distorted lens. Indeed, lexical and semantic analysis of social media content suggests that the need to revisit former selves in order to reconstruct life stories is a motive of users who post nostalgia-related material. Cluster analyses of large samples of nostalgia-related Facebook posts have identified themes of "Story” and “Appreciation of Life” in the semantic content (Davalos et al., 2015), and research examining social media trends has identified enhanced "storytelling" capabilities as a theme likely to affect multiple platforms in upcoming years (Lascu, 2016).

More generally, ontological security can be established and maintained via the longterm relationships the self has with others. The past must be real because so many important connections with other characters in the life story have been maintained to the present day. Indeed, research has found that a lack of perceived social connectedness is often associated with feelings of ontological insecurity (Ambreya, Bosman \& Ballard, 2018). If somebody feels all alone, then there is no way for others to validate their past.

Along these lines, previous research has identified the maintenance of "supportive and sociable relationships”, "strong social feelings of belonging”, and "a sense of shared identity” as primary motivations for social media users (Brandtzaeg \& Heim, 2009, p. 143). Other studies have found that social media users are “deepening salient aspects of one’s self through social interactions” and “maintaining interpersonal connectivity” (Dholakia et al., 2004, p. 244). Feeling embedded in a virtual if not physical community provides a sense of ontological security because the relationships are real. All of these online communications confirm that the recipient actualy exists (Sanchez-Franco, Buitrago-Esquinas \& Yniguez, 2012).

Indeed, social media users deliberately seek the acknowledgement and approval of their personal experiences by others, suggesting self-affirmation as an underlying motive. Some 
social media platforms even provide metrics that allow users to keep track of their social capital in terms of likes, comments, and monthly and annual summaries of responses from peers in a kind of ranking system for the social embeddedness of each life represented on the platform (Munar \& Jacobsen, 2014). More generally, social media platforms provide summaries of all the people the user has a relationship with, including family members, friends, school mates, work colleagues, teammates, etc., and this overall social network can be sub-divided and organised according to where and when relationships first started, embedding the self in a narrative of personal associations spanning space, and more importantly, time.

\section{Memory bias and autobiographical coherence}

As consumers pursue ontological security via self-validation and establishing a sense of continuity over time, there is considerable evidence that their memories distort in order to maintain autobiographical coherence - a sense that their lives are stories with themselves as the protagonist (Bluck \& Habermas, 2000; Freeman, 2001; McAdams, 2001). Yet, integrating the past into a coherent life story is inherently difficult because life itself, as experienced on a moment-by-moment basis, is not inherently biographical. Hence, memories of previous experiences and earlier versions of the self are distorted over time in order to create a narrative structure.

Consumers construct biographically coherent life stories out of remembered experiences according to three overarching sources of memory distortion: (a) life as experienced includes many negative experiences, but life tends to be remembered in more positive terms; (b) life as experienced includes innumerable unique but superfluous details, but life tends to be remembered in terms of stereotypes and schemas; and (c) life as experienced is often fragmented and disjointed, but life tends to be remembered as a coherent narrative (Alba \& Hasher, 1983; Taylor, 1989; Wilson \& Ross, 2003). 
Specific types of memory bias play an essential role in maintaining a self-affirming life story by altering the memories of what an individual once saw, heard, tasted, smelled and felt to become increasingly autobiographical over time. It is well beyond the scope of this theory to review all forms of memory bias, but a few are particularly relevant for understanding how people construct life stories out of their memories. Schemas are implicit theories, stereotypes, and other mental generalisations consumers develop in order to make sense of and act in the world around them. Consumers tend to remember past events as being more consistent with their schemas than those experiences actually were at the time (Alba \& Hasher, 1983; Payne et al., 1996).

For example, vacations often feature prominently in people’s life stories (Belk, 1991, Belk \& Yeh, 2011), whether they are honeymoons, journeys to special parts of the world, or trips involving special activities like skydiving or mountain climbing (Zauberman, Ratner \& Kim, 2008). Not surprisingly, vacation photos tend to feature rather prominently in Facebook profiles as significant events that remain in people's timelines long after they have concluded (Boley, Mancini \& Tuten, 2013; Munar \& Jacobsen, 2014). Yet, people tend to remember vacations as being far more enjoyable than they were as experienced at the time. The schema for a vacation is of a fun, potentially life-changing experience, so consumers tend to remember their holidays that way, editing out annoying experiences like being stuck in traffic on the way to the airport, sitting next to a screaming two-year old for seven hours on the plane, the rude and dismissive waiter at the restaurant, etc. (Mitchell et al., 1997).

Present bias occurs when memories are distorted so as to make sense given current circumstances. The past makes more sense when it can be reconciled with the present. For example, parents feature prominently in life stories (McAdams et al., 2006), but people tend to remember their parents as being more consistent with contemporary gender roles than they actually were at the time. Longitudinal research, wherein respondents take the same survey 
multiple times throughout their lives, has shown that middle-aged men tend to remember their mothers as having far more authority over household expenditures than they reported as teenage respondents. Contemporary women have far more autonomy now than in the past, leading middle-age respondents to project current levels of female autonomy and authority onto their memories of their teen-age years (Draaisma, 2013; Lilienfeld, Lynn, Ruscio \& Beyerstein, 2010).

Temporal amalgamations distort memory because people are not always accurate in remembering when an experience occurred relative to other remembered experiences, and because of this limitation, often unintentionally combine memory traces from different points in time into a single "remembered" event. Vacation experiences again provide a context for how this memory bias influences the construction of life stories. Memory traces from different vacations can easily be amalgamated into an "experience" that never actually occurred. Taking a subsequent trip to the same destination is particularly likely to result in this kind of memory bias, possibly "contaminating” memories of the initial vacation to that location (Zauberman et al., 2008).

Another relevant form of memory bias involves source monitoring errors. People cannot always accurately identify the origin of a memory, so they wind up misattributing it to the wrong source. For example, when people are told that they experienced something on vacation by a credible source like a parent or older sibling, they come to believe that a completely fabricated experience actually occurred, even adding details to the fictitious account. Subsequent exposure to advertising materials or other video content about a previously visited tourist destination can become entwined with autobiographical memories such that people become convinced that they actually experienced these scenes firsthand (Braun-LaTour, Gridley \& Loftus, 2006; Braun-LaTour et al., 2004). 
In summary, the pursuit of biographical coherence in the life story involves systematic distortion of memory, which occurs via multiple forms of memory bias, often occurring at an unconscious level without consumers necessarily being aware of how their personal pasts have been modified. When it comes to remembering past experiences, accuracy is often sacrificed for meaning, self-affirmation, and biographical coherence.

\section{Discussion and implications}

For much of human history the need for ontological security was minimal and relatively easy to maintain. Lifespans were objectively much shorter until the last 150 years or so, and existence was more repetitive and consistent on a daily, monthly and annual basis, so there was less “remembered past” to keep track of. Different generations were inherently connected to one another via their shared life experiences, and the number of people, places, and technological innovations experienced over the course of a lifetime was much smaller. Moreover, societal institutions, especially religion, provided coherent prescriptions for how to live a "good life”. Modernity has complicated the maintenance of ontological security, relatively suddenly in terms of human history, by fracturing human existence, multiplying the

number of people, places, technologies, and more generally, increasing the number of distinct events comprising a life, while at the same time reducing the influence of institutions that once provided prescriptions for how to live.

The popularity and rapid growth of social media platforms like Facebook and YouTube may simply reflect their usefulness for filling this modern psychological void. Users can create their own idiosyncratic life-affirming stories using self-produced video documentation of their experiences arranged and re-arranged along with the "likes”, emojis, GIFs, and comments from people in their immediate social networks. At the same time, content 
provided by others outside their social network offers consumers the possibility of recapturing forgotten experiences from a more distant past. The comments of other users verify and validate these previous versions of the self, reintegrating them into an ongoing life. Unconscious memory biases allow consumers to assimilate bits and pieces of their pasts into autobiographically coherent, self-affirming “life stories”, hence providing them with a sense of ontological security.

In addition to explaining the rapid increase in social media usage, the theory advanced above is useful for understanding certain recurring cultural themes in how people represent the past in their memories. For example, an apparent anomaly in previous research is that, although the self-concept tends to improve over time (i.e., "if I knew then...”), people nevertheless believe that life was better in the past (i.e., “...better in my day”). People tend to believe that they are better at the age of 55 than they were at the age of 25 , when they were naïve, reckless, narrow-minded, selfish, and so on; yet nostalgia research suggests that they long for the days of their youth. Is the past remembered as being better or worse than the present?

This apparent contradiction can be resolved by considering the need to maintain a selfaffirming life story. The protagonist of the life story has a need to feel good about themselves and one way to do this is to contrast their current self with earlier versions. People want to believe that they are learning about life as they pass through it and that this learning enables them to become better over time (Taylor, 1989). The tempestuous teen years, philandering young single adult years, etc. can be dismissed as more naïve former selves with incomplete views about what truly matters in life. The present self has replaced this ignorance with wisdom gained from life’s lessons and the school of hard knocks (Wilson \& Ross, 2003). This is all part of maintaining a self-affirming life story - the protagonist must improve over time. What about the "better in my day" motif of so many nostalgia experiences? This seems to 
imply that the life story is getting worse, but upon closer inspection, this mindset also affirms the life of the protagonist using a different point of comparison. The better in my day motif compares the past self to the present selves of younger generations, in essence saying, "When I was your age I was better than you are now"; an obvious boost for the protagonist of the life story.

Closely related to the "better in my day" mindset is the tendency for older generations to fear and demonise new technology. Today the cause de celebre is the smartphone, combined with social media. There have been calls to put warning labels on these devices to prevent teenagers from becoming "addicted” (Williams, 2015). Some of the people calling for these warnings might reflect on their own childhoods when the apocalyptic technological innovation of the day was the television, which was referred to as the "boob tube" or the "idiot box", was going to turn youth into uneducated zombies, and might even make them go blind if they sat too close (see Finn, 1992; Mcllwraith et al., 1991). There are multiple reasons for the animosity of older generations toward new technology, but one motive involves a threat to ontological security. New ways of doing things create a disconnection with the past. Old habits, rituals, pastimes, and routines are gone forever, and at an unconscious level, this invalidates part of the older generation’s life story; their pasts become obsolete. Hence, older generations demonise new technology in much the same way that they denigrate remakes of cherished television shows, movies, and songs from the past - they wish to keep their past relevant.

If impending mortality is the ultimate prompt to delve into our personal pasts and recollect and reorganise the pieces of our lives into a coherent, self-affirming narrative (Routledge et al., 2013), then it should hardly be surprising that narrative gerontology, a nascent form of therapy, has delivered positive outcomes in terms of improving the emotional states of aged care patients. The idea is simple enough. Get aged care patients to recall and 
talk about personal events from their pasts. Narrative gerontology has been associated with numerous positive psychological outcomes, including reduction of depression symptoms and increases in self-esteem, well-being, and overall satisfaction with life (Meléndez, Moral, Terrero, Galán \& Rodríguez, 2015).

One specific version of this approach is called the life-story group. A small group of aged care patients are asked to remember particularly happy, significant, or otherwise meaningful, events from an earlier part of their lives and share the stories with the others, who are invited to share their own related experiences from the same period. What emerges is a participatory group discussion of some period of yesteryear, all centred on the personal experiences of one or more members of the group. This same technique provides benefits for older people who are not in an aged care facility (Miller, 2011). Life story groups are remarkably similar to the kinds of exchanges occurring on Facebook and YouTube in response to nostalgia-evoking stimuli. Future research might assess possible therapeutic outcomes of these social media exchanges. If these digitally mediated discussions have the effect of increasing ontological security, then some of the positive outcomes associated with life story groups may also emerge among participants in social media nostalgia forums, at a much lower cost to patients and society in general.

Memories of our personal pasts may have become too numerous and fragmented than our need for ontological security can tolerate. If nostalgia involves not only the remembrance of earlier life events, but also the motive to construct a self-affirming yet believable life story, then the need to "shave off the rough edges" of one's remembered past and re-assemble the pieces into a linear narrative may require greater commitments of time to reminiscing. Perhaps social media content will force consumers to strike a new balance between living in the present and remembering and reconstructing the past. Social media platforms like 
Facebook may have to continually add features to the Timeline function in order to facilitate consumers' quests for ontological security in the $21^{\text {st }}$ century.

\section{References}

Acharjee, S. (2016). Look Up: Social Media and the Addiction No One Is Talking About. Alexandria, NSW: Hay House Publishers.

Alba, J. W., \& Hasher, L. (1983). Is memory schematic? Psychological Bulletin, 93(2), 203231. doi: 10.1037/0033-2909.93.2.203

Ambreya, C.L., Bosman, C. \& Ballard, A. (2018). Ontological security, social connectedness and the well-being of Australia’s ageing baby boomers. Housing Studies, 33 (5), 777 812.

Amigo, B., Osorio, F. \& Bravo, M.C. (2017). Mobile communication technologies and ontological security. Convergencia: Revista de Ciencias Sociales, 74, 39-61. doi: 10.29101/crcs.v0i74.4381

Anderson, B., Fagan, P., Woodnutt, T. \& Chamorro-Premuzic, T. (2012). Facebook psychology: popular questions answered by research. Psychology of Popular Media Culture, 1 (1), 23-37. doi: 10.1037/a0026452

Bailey, N. \& Areni, C.S. (2006). Background music as a quasi-clock in retrospective duration judgments. Perceptual \& Motor Skills, 102(2), 435-444. doi: 10.2466/pms.102.2.435444

Bassett, D.J. (2015). Who wants to live forever? Living, dying and grieving in our digital society. Social Sciences, 4, 1127-1139. doi:10.3390/socsci4041127

Bauman, Z. (2000). Liquid Modernity. Cambridge, UK: Polity Press. 
Bauman, Z. (2007). Liquid Times: Living in an Age of Uncertainty. Cambridge, UK: Polity Press.

Becker, E. (1973). The Denial of Death. New York: The Free Press.

Bell, G. \& Gemmell, J. (2009). Total Recall: How the E-Memory Revolution Will Change Everything. New York: Dutton.

Belk, R.W. (1988). Possessions and the extended self. Journal of Consumer Research, 15, 139-168. doi: 10.1086/209154

Belk, R.W. (1991). Possessions and the sense of past. In Highways and Buyways: Naturalistic Research from the Consumer Behavior Odyssey, eds. Russell Belk, Provo, UT: Association for Consumer Research, pp. 114-130.

Belk, R.W. (2013). Extended self in a digital world. Journal of Consumer Research, 40, 477500. doi: $10.1086 / 671052$

Belk, R.W. \& Yeh, J.H-Y. (2011). Tourist photographs: signs of self. International Journal of Culture, Tourism, and Hospitality Research, 5(4), 345 -353. doi: $10.1108 / 17506181111174628$

Bluck, S. \& Habermas, T. (2000). The life story schema. Motivation and Emotion, 24 (2), 121-147. doi: 10.1023/A:100561533

Boley, B.B., Magnini, V.P. \& Tuten, T.L. (2013). Social media picture posting and souvenir purchasing behaviour: some initial findings. Tourism Management, 37, 27-30. doi: 10.1016/j.tourman.2012.11.020

Boym, S. (2001). The Future of Nostalgia. New York: Basic Books.

Brandtzaeg, P.B. \& Heim, J. (2009). Why people use social networking sites. In A.A. Ozok and P. Zaphiris (Eds.): Online Communities, LNCS 5621, Berlin: Springer-Verlag, pp. 143-152. doi: 10.1007/978-3-642-02774-1_16 
Braun-LaTour, K. A., Grinley, M. J., \& Loftus, E. F. (2006). Tourist memory distortion. Journal of Travel Research, 44(4), 360-367. doi: 10.1177/0047287506286721

Braun-LaTour, K.A., LaTour, M.S., Pickrell, J.E. \& Loftus, E.F. (2004). How and when advertising can influence memory for consumer experience. Journal of Advertising, 33(4), 7-25. doi: 10.1080/00913367.2004.10639171

Brenner, J. (2013). Pew internet: Social media. Pew Internet and American Life Project, February 13, 2007, http://pewinternet.org/Commentary/2012/March/Pew-InternetSocial-Networking-full-detail.aspx (accessed 14.01.18).

Canal Nostalgia (2018). https://www.youtube.com/user/fecastanhari/videos (accessed: 27/05/2018).

Cavanaugh, J. C. (1989). I have this feeling about everyday memory aging... . Educational Gerontology, 15(6), 597-605. doi: 10.1080/0380127890150604

Davalos, S., Merchant, A., Rose, G.M., Lessley, B.J. \& Teredesai, A.M. (2015). 'The good old days': An examination of nostalgia in Facebook posts. International Journal of Human-Computer Studies, 83, 83-93. doi: 10.1016/j.ijhcs.2015.05.009

Dholakia, U.M., Bagozzi, R.P. and Pearo, L.K. (2004). A social influence model of consumer participation in network-and small-group-based virtual communities. International Journal of Research in Marketing, 21(3), 241-63. doi: 10.1016/j.ijresmar.2003.12.004

Do You Remember? (2018). https://doyouremember.com/about-us (accessed: 27/05/2018).

Draaisma, D. (2013). The Nostalgia Factory: Memory, Time and Ageing. New Haven, CT: Yale University Press.

Duggan, M. (2013). Photo and video sharing grow online. Pew Internet and American Life Project, http://www.pewinternet.org/2013/10/28/photo-and-video-sharing-grow-online/ (accessed: 14/01/2018). 
Dupuis, A. \& Thorns, D.C. (1998). Home, home ownership and the search for ontological security. Sociological Review, 46(1), 24-47. doi: 10.1111/1467-954X.00088

Fielden, J.M. (2003). Grief as a transformative experience: Weaving through different lifeworlds after a loved one has completed suicide. International Journal of Mental Health Nursing, 12, 74-85. doi: 10.1046/j.1440-0979.2003.00271.x

Finn, S. (1992). Television “addiction?” an evaluation of four competing media-use models. Journalism \& Mass Communication Quarterly, 69(2), 422 - 435. doi: $10.1177 / 107769909206900216$

Frankl, V. (1959). Man’s Search for Meaning. Boston, MA: Beacon Press.

Freeman, M. (1998). Mythical time, historical time, and the narrative fabric of the self. Narrative Inquiry, 8(1), 45-46. doi: 10.1075/ni.8.1.03fre

Freeman, M. (2001). From substance to story: narrative, identity, and the reconstruction of the self. In Narrative and Identity, Brockmeier, J. \& Carbaugh, D. (Eds.), Philadelphia, PA: John Benjamins Publishing.

Gergen, K.J. (1990). The Saturated Self: Dilemmas of Identity in Contemporary Life. New York: Basic Books.

Giddens, A. (1991). Modernity and Self-Identity: Self and Society in the Late Modern Age. Stanford, CA: Stanford University Press.

Giunchiglia, F., Zeni, M., Gobbi, E., Bignotti, E. \& Bison, I. (2018). Mobile social media usage and academic performance. Computers in Human Behavior, 82, 177-185. doi: 10.1016/j.chb.2017.12.041

Gokcearslan, S., Mumcu, F.K., Haslaman, T. \& Cevik, Y.D. (2016). Modelling smartphone addition: The role of smartphone usage, self-regulation, general self-efficacy and cyberloafing in university students. Computers in Human Behavior, 63, 639-649. doi: 10.1016/j.chb.2016.05.091 
Gombrich, E.H. (1967). In Search of Cultural History, Oxford, UK: Clarendon Press.

Graham, C., Gibbs, M. \& Aceti, L. (2013). Introduction to the special issue on the death, afterlife, and immortality of bodies and data. The Information Society, 29(3), 133-141. doi: 10.1080/01972243.2013.777296

Hambleton, I.R., Howitt, C., Jeyaseelan, S. Murphy, M.M., Hennis, A.J., Wilks, R., Harris, E.N., MacLeish, M. \& Sullivan, L. (2015). Trends in longevity in the Americas: disparities in life expectancy in women and men, 1965-2010. PLOS ONE. doi: 10.1371/journal.pone.0129778.

Huang, X.I., Huang, Z.T. \& Wyer, R.S., Jr. (2016). Slowing down in the good old days: the effect of nostalgia on consumer patience. Journal of Consumer Research, 43, 372-387. doi: 10.1093/jcr/ucw033

Johnnyboy792 (2012). Memories of 1971? Where Were You? https://www.youtube.com/watch?v=GbMosumnUGE. (Accessed: 26/5/16) JoymanyMahn2 (2008). Zoom opening credits - Season 2, Cast 2. https://www.youtube.com/watch?v=I3AzdiWHEuc (accessed: 15/02/2016)

Ju, I., Kim, J., Chang, M.J. \& Bluck, S. (2016). Nostalgic marketing, perceived selfcontinuity, and consumer decisions. Management Decision, 54(8), 2063-2083. doi: 10.1108/MD-11-2015-0501

Juhl, J., Routledge, C., Arndt, J., Sedikides, C. \& Wildschut, T. (2010). Fighting the future with the past: Nostalgia buffers existential threat. Journal of Research in Personality, 44, 309-314. doi: 10.1016/j.jrp.2010.02.006

Kessous, A. (2015). Nostalgia and brands: a sweet rather than a bitter cultural evocation of the past. Journal of Marketing Management, 31(17-18), 1899-1923. doi: 10.1080/0267257X.2015.1088889 
Koetz, C. \& Tankersley, J.D. (2016). Nostalgia in online brand communities. Journal of Business Strategy, 37(3), 22-29. doi: 10.1108/JBS-03-2015-0025

Laing, R.D. (1965). The Divided Self. Gretna, LA: Pelican Press.

Landis, P.H. (1947). Social Policies in the Making. Boston, MA: D.C. Heath and Company. Lange, J.G. (2011). Video-mediated nostalgia and the aesthetics of technical competencies. Visual Communication, 10(1), 26-44. doi: 10.1177/1470357210389533

Lasaleta, J.D., Sedikides, C. \& Vohs, K.D. (2014). Nostalgia weakens the desire for money. Journal of Consumer Research, 41, 713-729. doi: 10.1086/677227

Lascu, C. (2016). Social Media Trends for 2017. London, UK: Carmen Lascu Publishing. Lilienfeld, S.O., Lynn, S.J., Ruscio, J. \& Beyerstein, B.L. (2010). 50 Great Myths of Popular Psychology: Shattering Widespread Misconceptions about Human Behavior. West Sussex, UK: Wiley-Blackwell.

Loveland, K.E., Smeesters, D. \& Mandel, M. (2010). Still preoccupied with 1995: the need to belong and preference for nostalgic products. Journal of Consumer Research, 37, 393408. doi: $10.1086 / 653043$

Lowenthal, D. (1985). The Past Is a Foreign Country. Cambridge, UK: Cambridge University Press.

Luchman, J.N., Bergstrom, J. \& Krulikowski, C. (2014). A motives framework of social media website use: A survey of young Americans. Computers in Human Behavior, 38, 136-141. doi: 10.1016/j.chb.2014.05.016

March, E. \& McBean, T. (2018). New evidence shows self-esteem moderates the relationship between narcissism and selfies. Personality and Individual Differences, 130(1), 107111. doi: 10.1016/j.paid.2018.03.053

McAdams, D. P. (2001). The psychology of life stories. Review of General Psychology, 5(2), 100-122. doi: 10.1037/1089-2680.5.2.100 
McAdams, D.P., Bauer, J.J., Sakaeda, A.R., Anyidoho, N.A., Machado, M.A., MagrinoFailla, K., White, K.W. \& Pals, J.L. (2006). Continuity and change in the life story: a longitudinal study of autobiographical memories in emerging adulthood. Journal of Personality, 74(5), 1371-1400. doi: 10.1111/j.1467-6494.2006.00412.x

McIlwraith, R., Jacobvitz, R.S., Kubey, R. \& Alexander, A. (1991). Television addiction: theories and data behind the ubiquitous metaphor. American Behavioral Scientist, 35(2), 104-121.

Meléndez, J.C., Moral, F.B., Terrero, F., Galán, A.S. \& Rodríguez, T.M. (2015). Effect of integrative reminiscence therapy on depression, well-being, integrity, self-esteem, and life satisfaction in older adults, Journal of Positive Psychology, 10(3), 240-247. doi: $10.1080 / 17439760.2014 .936968$

Michael, S.T. \& Snyder, C.R. (2005). Getting unstuck: the roles of hope, finding meaning, and rumination in the adjustment to bereavement among college students, Death Studies, 29(5), 435-458. doi: 10.1080/07481180590932544

Miller, B. (2011). Narrative gerontology: A post-modern reading of the latter stage of life: A conversation with William Randall. Journal of Systemic Therapies, 30(4), 64-75. doi: 10.1521/jsyt.2011.30.4.64

Mitchell, T.R., Thompson, L., Peterson, E. \& Cronk, R. (1997). Temporal adjustments in the evaluation of events: the "rosy view”. Journal of Experimental Social Psychology, 33, 421-448. doi: 10.1006/jesp.1997.1333

Munar, A.M. \& Jacobsen, J.K.S (2014). Motivations for sharing tourism experiences through social media. Tourism Management, 43, 46-54. doi: 10.1016/j.tourman.2014.01.012 Musicom Productions (2007). CLASSIC TV - 1960s - Captain Kangaroo Show Open. https://www.youtube.com/watch?v=q3w7w58CREY (accessed: 22/12/16). 
Nef, T., Ganea, R.L., Müri, R.M. \& Mosimann, U.P. (2013). Social networking sites and older users - a systematic review. International Psychogeriatrics, 25(7), 1041-1053. doi: 10.1017/S1041610213000355

Pannoni (2013). Captain Kangaroo - July 22, 1961. https://www.youtube.com/watch?v=brCNJHFdYFI\&t=60s (accessed: 22/12/16).

Pargament, K.I. (1997). Religious methods of coping: Resources for the conservation and transformation of significance. In Religion and the Clinical Practice of Psychology, Shafranske, E.P. (Ed.), Washington, DC: American Psychological Association, pp. 215239. doi: $10.1037 / 10199-008$

Pargament, K.I. (2002). The bitter and the sweet: An evaluation of the costs and benefits of religiousness. Psychological Inquiry, 13(3), 168-181. doi: 10.1207/S15327965PLI1303_02

Payne, D.G., Elie, C.J., Blackwell, J.M. \& Neuschatz, J.S. (1996). Memory illusions: recalling, recognizing, and recollecting events that never occurred. Journal of Memory and Language, 35, 261-285. doi: 10.1006/jmla.1996.0015

Pett, E. (2013). 'Hey! Hey! I've seen this one, I've seen this one. It's a classic’: Nostalgia, repeat viewing and cult performance in Back to the Future. Participations: Journal of Audience and Reception Studies, 10(1), 177-197.

Phipps, M. \& Ozanne, J.L. (2017). Routines disrupted: reestablishing security through practice alignment. Journal of Consumer Research, 44, 361-380. doi: 10.1093/jcr/ucx040

Pickering, M. \& Keightley, E. (2006). The Modalities of Nostalgia. Current Sociology, 54(6), 919-941. doi: 10.1177/0011392106068458 
Piper, H. (2001). Vintage entertainment: nostalgia, the archive and the disappearing pleasures of collective television viewing. Journal of British Cinema and Television, 8(3), 411429. doi: 10.3366/jbctv.2011.0047

Pornsakulvanich, V. (2017). Personality, attitudes, social influences, and social networking site usage predicting online social support. Computers in Human Behavior, 76, 255-262. doi: 10.1016/j.chb.2017.07.021

Poushter, J. (2017). Not everyone in advanced economies is using social media. Pew Research Centre. http://www.pewresearch.org/fact-tank/2017/04/20/not-everyone-inadvanced-economies-is-using-social-media/ (accessed: 14/01/2018).

Rajanala, S., Maymone, M.B.C. \& Vashi, N.A. (2018). Selfies-living in the era of filtered photographs. JAMA Facial Plastic Surgery. https://jamanetwork.com/journals/jamafacialplasticsurgery/fullarticle/2688763 (accessed: 11/08/2018). doi:10.1001/jamafacial.2018.0486

Rosenblatt, P.C., Walsh, H.P. \& Jackson, D.A. (1976). Grief and Mourning in Cross-Cultural Perspective. New Haven, CT: HFAR.

Routledge, C., Arndt, J., Sedikides, C. \& Wildschut, T. (2008). A blast from the past: the terror management function of nostalgia. Journal of Experimental Social Psychology, 44(1), 132-40. doi: 10.1016/j.jesp.2006.11.001

Routledge, C., Wildschut, T., Sedikides, C. \& Juhl, J. (2013). Nostalgia as a resource for psychological health and well-being. Social and Personality Psychology Compass, 7(11), 808-818. doi: 10.1111/spc3.12070

Sanchez-Franco, M.J., Buitrago-Esquinas, E.M. \& Yniguez, R. (2012). How to intensify the individual's feelings of belonging to a social networking site? Contributions from community drivers and post-adoption behaviours. Management Decision, 50(6), 11371154. doi: 10.1108/00251741211238373 
Savin-Baden, M., Burden, D. \& Taylor, H. (2017). The ethics and impact of digital immortality. Knowledge Cultures, 5(2), 11-29.

Senft, T.M \& Baym, N.K. (2015). What does the selfie say? Investigating a global phenomenon. International Journal of Communication, 9, 1588-1606.

Smith, A. \& Anderson, M. (2018). Social Media Use in 2018, Pew Research Center. http://www.pewinternet.org/2018/03/01/social-media-use-in-2018/ (accessed: 18/4/2018).

Storr, W. (2017). Selfie: How the West Became Self-Obsessed. London: Picador.

Taylor, C. (1989). Sources of the Self: The Making of the Modern Identity. Cambridge, MA: Harvard University Press.

Taylor, C. (2007). A Secular Age. Cambridge, MA: Belnap Press.

Tierney, J. (2013). What is nostalgia good for? Quite a bit, research shows. New York Times, 8 July, http://www.nytimes.com/2013/07/09/science/what-is-nostalgia-good-for-quite-abit-research-shows.html?pagewanted=all\&_r=2 (accessed: 05/10/17).

Trackalytics (2018). https://www.trackalytics.com/youtube/user/fecastanhari/ (accessed: 09/07/18).

van den Eijnden, R.J.J.M., Lemmens, J.S. \& Valkenburg, P.M. (2016). The social media disorder scale. Computers in Human Behavior, 61, 478-487. doi: 10.1016/j.chb.2016.03.038

Wells, T. \& Links, W. (2014). Facebook user research using a probability-based sample and behavioral data. Journal of Computer-Mediated Communication, 19, 1042-1052. doi: $10.1111 /$ jcc 4.12058

Wildschut, T., Bruder, M., Robertson, S., Tilburg, W. and Deidikides, C. (2014). Collective nostalgia: a group-level emotion that confers unique benefits on the group. Journal of Personality and Social Psychology, 107(5), 844-863. doi: 10.1037/a0037760 
Williams, R. (2015). Put warning labels on smartphones to prevent digital addiction, say researchers. The Telegraph, 6 October, http://www.telegraph.co.uk/technology/news/11914851/Put-warning-labels-onsmartphones-to-prevent-digital-addiction-say-researchers.html (accessed: 01/01/2018).

Wilmoth, J.R. (1998). The future of human longevity: a demographer’s perspective. Science, 280, 395-397. doi: 10.1126/science.280.5362.395

Wilmoth, J.R. (2000). Demography of longevity: past, present, and future trends. Experimental Gerontology, 35, 1111- 1129. doi: 10.1016/S0531-5565(00)00194-7

Wilson, A.E. \& Ross, M. (2003). The identity function of autobiographical memory: Time is on our side. Memory, 11(2), 137-149. doi: 10.1080/741938210

Wyatt, F. (1964). The reconstruction of the individual and of the collective past. In R.W. White (Ed.), The Study of Lives: Essays on Personality in the Honor of Henry A. Murray, New York: Atherton.

Zakay, D. \& Feldman, T. (1993). The role of segmentation and recallability in retrospective time estimation. Psychological Record, 43, 415-428.

Zauberman, G., Ratner, R.K. \& Kim, B.K. (2008). Memories as assets: strategic memory protection in choice over time. Journal of Consumer Research, 35, 715-728. doi: $10.1086 / 592943$

Zauberman, G., Levav, J., Diehl, K. \& Bhargave, R. (2010). 1995 feels so close yet so far: the effect of event markers on subjective feelings of elapsed time. Psychological Science, 21(1), 133-139. doi: 10.1177/0956797609356420

Zerubavel, E. (2003). Time Maps: Collective Memory and the Social Shape of the Past. Chicago, IL: The University of Chicago Press.

Zhao, X., Salehi, N., Naranjit, S., Alwaalan, S., Voida, S. \& Cosley, D. (2013). The many faces of Facebook: experiencing social media as performance, exhibition, and personal 
archive. In: Proceedings of the SIGCHI Conference on Human Factors in Computing Systems, pp. 1-10. doi: 10.1145/2470654.2470656

Zhou, L., Wang, T., Zhang, Q. \& Mou, Y. (2013). Consumer insecurity and preference for nostalgic products: Evidence from China. Journal of Business Research, 66, 24062411. doi: 10.1016/j.jbusres.2013.05.027

Zickuhr, K. \& Madden, M. (2012). Older adults and internet use. Pew Research Centre. http://pewinternet.org/Reports/2012/Older---adults---and---internet---use.aspx (accessed: 05/01/2018). 